\title{
Rethinking the impacts of foreign investors on urban development: the city of Macao
}

\section{Li Sheng}

Received: 26 February 2010 / Accepted: 27 December 2010 / Published online: 12 January 2011 (C) Springer-Verlag 2011

\begin{abstract}
A number of papers in the economics and urban literature find positive impacts of foreign investment on cities and praise the role of foreign investors in urban development. The author argues for a different stance by developing an urban economics model for tourist cities. The model illustrates that in the presence of significant side effects, foreign investors' and a tourist city's preferences regarding openness of the city greatly diverge. Foreign investors tend to shape a city's policymaking toward greater openness. Therefore, policymakers in tourist cities concerned about sustainable development should carefully regulate foreign capital inflows at an optimal level. Evidence from Macao lends support to the theoretical construction.
\end{abstract}

\section{JEL Classification $\quad \mathrm{F} 23 \cdot \mathrm{R} 11$}

\section{Introduction}

Market fundamentalists and some international organizations, such as the International Monetary Fund (IMF), the World Bank, the World Tourism Organization, and the World Economic Forum, enthusiastically urge cities to seek competitive advantages as a means of survival and prosperity. Based on an assumption that inter-city competition for foreign investment is escalating, these organizations advocate that cities create market conditions that attract foreign investors to invest and exploit local competitive advantages. The desirability of foreign investment is backed by a large volume of the economics literature. According to these studies, foreign capital inflow has various advantages, such as stimulating economic growth (Dutt 1997; Zhang and Felmingham 2001), intensifying inter-firm competition (Wu and Barnes 2008; Anwar 2009), acquiring advanced technology and management skill (Peri and Urban 2006;

L. Sheng $(\bowtie)$

Gaming Teaching and Research Centre, Macao Polytechnic Institute,

Edif. Kind Light Garden, Rua de Chiu Chau, No. 48-52, Taipa, Macao

e-mail: edmundsheng@ipm.edu.mo 
Lloyd 1996), cultivating policy transparency and market discipline (Relly and Sabharwal 2009), enhancing efficiency in financial markets (Wei et al. 2006). Within the urban studies literature, there are a number of empirical papers offering support to the claimed positive impacts of foreign investors. Wei et al. (2006) find significant contributions by foreign investors in increasing external trade, global city and financial center formation, as well as overall rapid economic growth in the city of Shanghai. Wu (2001) finds significant contributions by foreign investors to development finance in China. This contribution makes large-scale infrastructure and prestigious, high-profile projects possible and helps to transform Chinese cities from a mixed, cellular pattern to a highly differentiated pattern of land uses. Turnock argues (1997) that foreign investors help to accelerate urban restructuring, exploit comparative advantages, and situate Eastern European cities within the global division of labor. Foreign investment also stimulates competition by pushing domestic enterprises into an innovative mode. Positive evaluations of the impacts of foreign investors on urban development can also be found in Campbell (2009), Chou and Chow (2009), Huong and Sajor (2010), Kim (2010), Musil (2009), and Özdemir (2010).

However, in the tourism geographies literature, many studies bear witness to the serious side effects accompanying the overgrowth of tourism, which is largely driven by foreign investment. Economic side effects, such as leakage, increased cost of living, and asset bubbles, are documented in Copeland (1991), Wilkinson (1999), Scheyvens and Momsen (2008), Potter (1993), Hoti et al. (2005), Harrison (2003), Chand (2003), Sheng and Tsui (2009a, 2010), Mowforth and Munt (2003), and Croes (2006). Environmental side effects, such as air pollution, noise pollution, and the overuse of natural resources, are analyzed in Briassoulis (2002), Wilkinson (1999), Liu and Jenkins (1996), Tang and Sheng (2009), Rafiqui and Gentile (2009), Sheng and Tsui (2009b), and Gössling (2001). Social side effects, such as increased crime, social polarization, and cultural alienation are illustrated in Shaw and Shaw (1999), Carbone (2005), Scheyvens and Momsen (2008), Kirby and Modarres (2010), Ghosh et al. (2003), Williams and Hall (2000, 2002), Sheng and Tsui (2009c), Gössling and Schulz (2005), and Stonich (2003).

In this paper, we explore the different preferences of foreign investors and host communities with regard to a city's openness. For this purpose, we develop an urban economics model for tourist cities, illustrating how the interests of foreign investors and host communities might diverge in the presence of significant side effects. We focus on a city's degree of openness and show the rational preferences of host communities and foreign investors. Note that a "tourist city" in this paper is defined as a city in which the tourism sector has a large share in the local economy and where the host community is mainly a provider, not a consumer, of tourism services. After theoretical modeling, a case study of Macao is presented, lending support to the theoretical construction because Macao, a booming tourist city that has experienced spectacular growth since its gaming sector was liberalized to foreign investors, has also suffered from serious socio-economic side effects (Sheng and Tsui 2009b). By critically re-evaluating the negative impacts of massive foreign capital inflows in the case study, this paper attempts to balance the prevailing views in the existing literature and to inspire city planners to formulate more comprehensive foreign investment policies. 


\section{The model}

\subsection{Variables}

This section explores how a tourist city makes a sensible tradeoff between economic growth and its side effects. This tradeoff is based on the city's preferences over the opportunities offered by foreign capital inflows. The model addresses a particular research question as to why free capital mobility may do more harm than good for a tourist city. Let $a$ denote the extent of openness in a tourist city toward international capital, with $(1-a)$ considered to be the intensity of the city's control over foreign capital inflows. The variable $a$ ranges from 0 (pure closed) to 1 (pure open). By openness, we refer to whether the main city development strategy orientation is open, closed, or moderate (between the two extremes) toward international capital. An open strategy, usually driven by a simple belief that "more is better", describes an indiscriminately open and welcoming attitude toward foreign investment. A closed strategy, on the contrary, is a reluctance to open the city up to foreign factors of production. The United Nations World Tourism Organization (UNWTO) and the United Nations Environment Program (UNEP) (1997) define "tourism carrying capacity" as the maximum number of tourists that may visit a location at the same time without causing destruction to the city's physical, economic, or socio-cultural environment, or an unacceptable decrease in the quality of residents' and visitors' satisfaction. A city's carrying capacity may vary over time, and different cities have different carrying capacities. Whereas cities with a limited carrying capacity may experience severe side effects, cities with a large carrying capacity can accommodate large numbers of tourists without suffering from significant side effects. Let $b$ denote the city's degree of vulnerability to side effects, ranging from 0 (the least vulnerable) to 1 (the most vulnerable). Obviously, vulnerability is negatively related to the city's tourism carrying capacity. Let $\sigma$ denote the severity of the side effects due to a massive inflow of foreign capital into the city. The overall index $\sigma$ includes any capital flow-related negative effects, including leakage, inflation, asset bubbles, "Dutch disease", environmental degradation, etc. Side effects, $\sigma$, increase with wider openness (a larger $a$ ) and with increased vulnerability (a larger $b$ ).

The side effects function $\sigma=\sigma(a, b)$, satisfying the properties of $\partial \sigma / \partial a>0$ and $\partial \sigma / \partial b>0$, is assumed to be concave, so a typical iso-side effects curve is decreasing and convex, as shown in Fig. 1. All $(a, b)$ combinations on this curve are associated with the same level of side effects; a higher curve displays a greater level of side effects, e.g., $\sigma_{o}>\sigma_{o}^{\prime}$. For a given level of side effects, $\sigma_{o}$, the move from point $A$ to point $B$ suggests the need to tighten controls over foreign capital inflows as the city becomes more vulnerable to side effects, and the $A$-to- $B^{\prime}$ move indicates the feasibility of loosening controls as the city becomes less vulnerable. For any given degree of openness, enhancing the tourism carrying capacity (as in the $B$-to- $C$ move) can decrease side effects $\left(\sigma_{o}\right.$ falls to $\left.\sigma_{o}^{\prime}\right)$. For a given level of side effects, a widening of openness (such as the $C$-to- $D$ move) may increase side effects ( $\sigma_{o}^{\prime}$ rises to $\sigma_{o}$ ). More capital controls are needed to reduce side effects when the city's tourism carrying capacity is limited (see a move from $D$ to $C$ ). Because it is difficult to strengthen the tourism carrying capacity by giving it a lower value of $b$ in the short term, it is reasonable to treat $b$ 


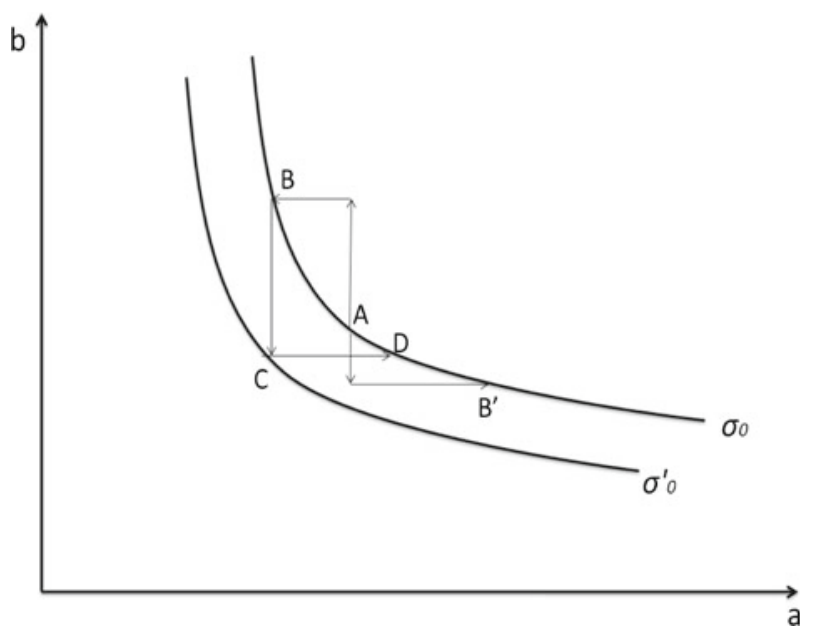

Fig. 1 The iso-side effects curves

as a given parameter and to take $a$ as a choice variable in our analysis. Thus, we can rewrite $\sigma=\sigma(a, b)$ as $a=a_{\sigma}(b)$ to determine the degree of openness $a$ based on vulnerability $b$ given a tolerable level of side effects $\sigma$.

\subsection{Growth, openness, and side effects}

A city's openness provides a certain opportunity for economic growth; however, it also leads to various side effects, as documented in the extant literature. Let $g$ denote the city's expected growth, which initially accelerates with more international capital under wider openness (a larger $a$ ), then reaches a maximum at some intermediate level of capital flows $\left(a_{m}<1\right)$, and then decelerates as capital flows expand with an even larger $a$. Admittedly, the marginal benefit from capital flows, in terms of average economic growth, is diminishing with increasing capital inflows as $a<a_{m}$, and it may become negative afterward when $a>a_{m}$. The relationship between growth and openness, $g=G(a)$, can also be explained as that between growth and side effects, $g=g(\sigma)$, as capital flows are significantly positively related to vulnerability or side effects. The derived curve $g=g(\sigma)$ indicates risky opportunities for the city's economic growth, with the risk of side effects rising when the city's openness goes beyond its optimum. We verify the two equivalent forms of the risky opportunity relation: $g=g(\sigma)=g\left(\sigma_{b}(a)\right)=G(a)$ if suppressing $b$ after using $\sigma=\sigma(a, b)=\sigma_{b}(a)$. Plotting this relation on the side effects-growth plane gives the opportunity curve $g=g(\sigma)$, which seen in Fig. 2, for a tourist city. In this curve, each point corresponds to a different degree of openness. This objective set of side effects-growth substitutions is beyond the city's control in the short run and constrains its policy choice by providing it with the opportunities for growth. Note that these are coupled with the risks of side effects. The curve $g(\sigma)$ is assumed to be concave due to diminishing growth benefits from capital flows, and it satisfies the properties of $d g / d \sigma>0$ for $\sigma<\sigma_{m}$ and $d g / d \sigma<0$ for $\sigma>\sigma_{m}$. 


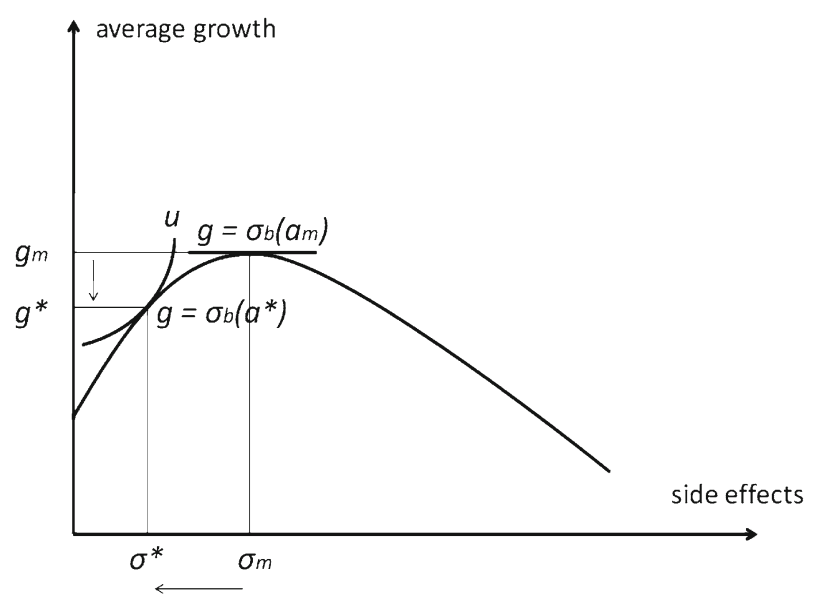

Fig. 2 The optimal tradeoff between average growth and side effects

Most tourist cities pursue rapid growth under pressure to lower high unemployment by allowing large capital inflows, but these cities are also risk-averse and cannot accommodate endless capital flows without caring about the accompanying risk of side effects. Expected growth (as a good) and side effects (as a bad) are treated as the objects of choice by a tourist city and should enter the welfare function $u=u(\sigma, g)$ in such a way that the marginal utilities satisfy $M U_{\sigma}<0$ and $M U_{g}>0$. The indifference curves in Fig. 2 associated with this utility function reflect subjective tradeoffs between side effects and growth for the tourist city, indicating a higher level of utility when moving upwards (higher growth) and/or leftwards (less side effects). Only one of the city's indifference curves is tangent to its opportunity curve, and the tangency point gives the optimal decision on side effect-growth tradeoffs $\left(\sigma^{*}, g^{*}\right)$ and its optimal choice of openness $a^{*}$. This is a constrained optimization problem: $\max _{(\sigma, g)} u=u_{c}(\sigma, g)$, s.t. $g=g_{b}(\sigma)$, which can be changed to an unconstrained optimization problem: $\max _{\sigma} u=u_{c}\left(\sigma, g_{b}(\sigma)\right)$. The optimal solution to the second problem should include $\sigma^{*}=\sigma(b, c), g^{*}=g\left(\sigma^{*}\right)=g(\sigma(b, c))=g(b, c)$, and $a^{*}=a_{\sigma^{*}}(b)=a_{\sigma^{*}(b, c)}(b)=$ $a(b, c)$.

Different cities have different attitudes toward side effects, reflected in differently shaped indifference curves. For a poor city, the local government may be inclined to pursue rapid growth by permitting massive tourist arrivals, foreign investment, and foreign labor despite the potential risks. Suppose this city has a lower value of $c$ representing its policy preferences, i.e., more growth-prone and less side effects-averse, the city should then have a flatter set of indifference curves. As a result, the optimal tradeoff for this city will be with more side effects and faster growth made possible by increased tourist arrivals, foreign investment, and foreign labor under a wider openness standard. One sees for this situation that $\partial \sigma^{*} / \partial c<0, \partial g^{*} / \partial c<0$, and $\partial a^{*} / \partial c<0$. This shows that increased side effects are the inevitable price paid for higher growth $\left(d g^{*} / d \sigma^{*}>0\right.$ through the $c$-channel, a complementary relationship between $\sigma^{*}$ and $\left.g^{*}\right)$ under the more liberal openness policy ( $\partial a^{*} / \partial c<0$ as $c$ goes down). A different 
city may have a larger tourism carrying capacity and consequently be more tolerant of the side effects accompanying rapid tourism growth.

\subsection{Foreign investors and urban policymaking}

This section presents a simple model that reveals the economic reason why foreign investors pressure their tourist cities counterparts to open ever wider to international capital. The tradeoffs are equivalent to those between side effects and growth for tourist cities as shown above. Consider a world consisting only of two economies, a tourist city (denoted by $A$ ) and a foreign investor (denoted by $B$ ). The indifference curve $u$ and the opportunity set $g$ for $A$ have been discussed earlier; let us now specify those two curves for $B$. Because both parties are seeking high growth $g$ but are averse to severe side effects $\sigma, B$ 's welfare function $u=u_{B}(\sigma, g)$ exhibits similar properties to $A$ 's $u=u_{A}(\sigma, g): M U_{\sigma}<0$ and $M U_{g}>0$. A significant difference between the two economies may be that $B$ is less risk-averse than $A$ because the former is less vulnerable than the latter in dealing with side effects. $A$ 's growth, as induced by investment from $B$, will enhance the former's ability to import from the latter, and this positive spillover effect will be reinforced via a closer economic partnership between the two parties. If openness in $A$ is too wide for capital flow to be manageable, side effects may arise, threatening $A$ 's economic growth. As $A$ 's ability to import from $B$ is weakened and its profits from $B$ 's operations in $A$ are reduced, $B$ 's growth will be adversely affected in turn. Therefore, we assume that $B$ 's growth $g=G(a)$ initially rises with $A$ 's widened opening $a$, then reaches a peak at some level of $a_{m}^{\prime}$, and finally declines as foreign openness becomes even greater. Combining $g=G(a)$ with $\sigma=\sigma(a)$, we discover a relationship between growth $g$ and side effects $\sigma$ as the opportunity curve for $B$; that is, $g=g_{B}(\sigma)$ with $d g / d \sigma>0$ for $\sigma<\sigma_{m}^{\prime}$ and $d g / d \sigma<0$ for $\sigma>\sigma_{m}^{\prime}$, as shown in Fig. 3.

$B$ tries to maximize growth and minimize side effects given the opportunity for free capital inflows into $A$. $B$ 's optimal tradeoff between growth and side effects occurs at a different level of openness than does $A$ 's. We put the tradeoffs by both economies into the same diagram for comparison, as depicted in Fig. 3. $O_{A}$ is on the left, and $O_{B}$ is on the right, with the $\sigma$ axes pointing in opposite directions. The tangency point $B$ indicates $A$ 's openness as optimal for $B$, with domestic growth $g_{B}^{*}$ and instability $\sigma_{B}^{*}$, reaching a maximum utility of $U_{B}^{*}$. For $A$, the optimal side effects-growth tradeoff would need to be $\left(\sigma_{A}^{*}, g_{A}^{*}\right)$ for the maximum possible level of utility $U_{A}^{*}$ to be attained. On the one hand, control over foreign capital inflows would make $B$ worse off because its utility is only $U_{B}^{\prime}$ and could thus be improved. On the other hand, capital mobility freedom as requested by $B$ would reduce $A$ 's utility down to $U_{A}^{\prime}$. It is obvious that both parties have keen conflicts of interests with regard to capital mobility.

The ultimate equilibrium depends on the relative bargaining power of both parties. If foreign investors dominate the city's decision-making, the equilibrium may approach $\sigma_{m}^{*}$, which indicates large benefits for foreign investors and less benefit, or even a loss of utility, for the host community. This situation is possible, as Sheng and Tsui (2010) illustrate that powerful multinational enterprises, backed by their governments, collaborate with local politicians and push for foreign investment 


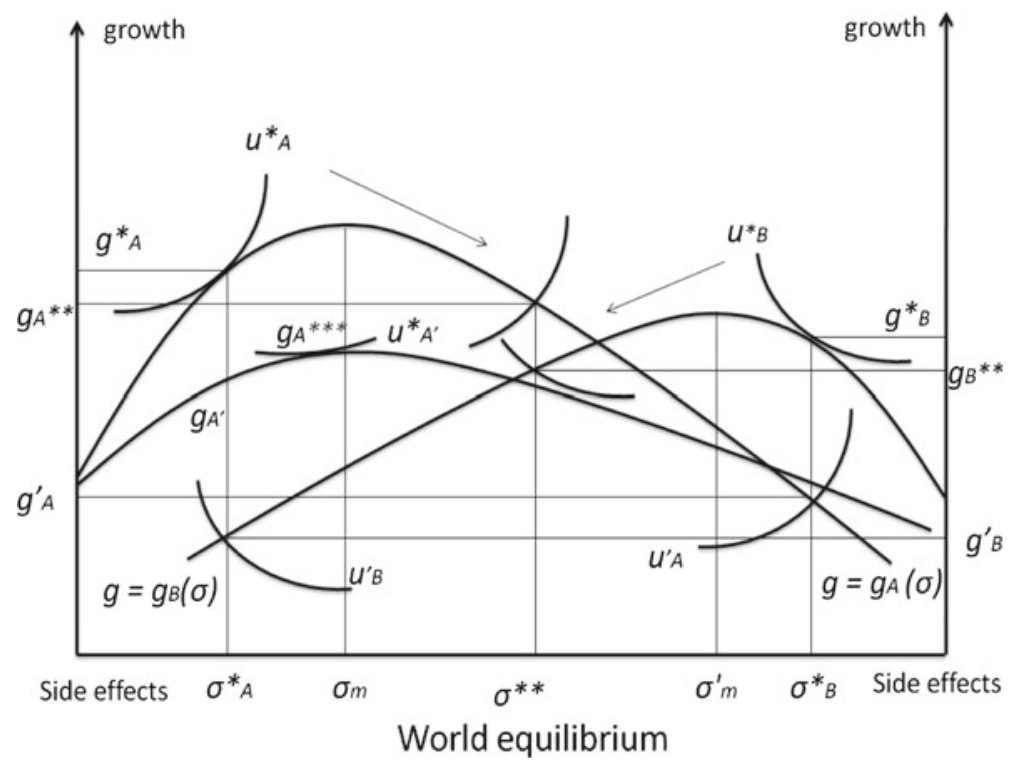

Fig. 3 Conflicts of interest between foreign investor and host community

policies that favor foreign investors at the expense of the host community. On the other hand, if a majority of the host community successfully takes concerted actions and effectively defends their rights with regard to openness of the city, the ultimate equilibrium may approach $\sigma_{A}^{*}$, with smaller gains for foreign investors but better gains for locals. This situation is possible if the policymaking process is based on a broader democratic decision-making system, so that local community as a whole possesses stronger bargaining power relative to foreign investors (Sheng and Tsui 2009a). Note that what we illustrate is a short-run situation. In the long run, massive inflows of foreign investment inevitably change the tourism carrying capacity and vulnerability of the city to side effects, so that exogenous variables become endogenous ones. The growth function and utility function will also change accordingly. Therefore, the short-run static equilibrium may become a dynamic one in the long run.

It is worth mentioning that without needed foreign capital, advanced management experience, and technology brought in by foreign investors, the city's local development may be far below its optimal level. This is the case in many tourist cities in developing countries, as they may not possess unique resources and are lacking in land, human resources, and capital; thus, the overall development level before the opening is low. Therefore, they may have no alternative than to open wider and wider. Graphically, we have a lower growth curve line $g_{A^{\prime}}$ and a flatter utility curve $u_{A^{\prime}}^{*}$; the optimum may be at $g_{A^{* * *}}$, as shown in Fig. 3. Consequently, the city is ready to accommodate more capital inflow to stimulate its economic growth while being willing to bear more side effects. In this case, the interests of host communities and foreign investors may converge. 


\section{The case of Macao}

\subsection{Side effects of the Casino Boom}

The city of Macao is one of China's two special administrative regions (SARs), and it enjoys legislative, executive, and judicial power constitutionally independent from Beijing, in addition to having its own currency. It is a free port without any control over foreign investment. Following a liberal economic doctrine, the government of Macao provides numerous foreign investment facilitation measures. With a territory of $29.5 \mathrm{~km}^{2}$ and a population of 544,100 , the city reported a GDP of 169.3 billion Patacas (8 Patacas for 1 USD) in 2009, making it one of the world's richest economies. The backbone of Macao's economy is tourism, especially casino gambling, with tourist spending making up nearly 90\% of Macao's GDP. Over half of Macao's labor force is employed in tourism-related sectors, and around two thirds of public revenues are created by the gaming industry (Macao Statistics and Census Services 2009).

Macao has been experiencing a spectacular economic boom since 2002, with an average annual GDP growth rate of $20 \%$. The main driving force for the ongoing boom is that its gaming industry was liberalized to foreign investors in 2002 . With this broader opening, huge amounts of foreign investment have been flowing into the city. While net foreign capital inflow (capital inflow minus outflow) amounted to 3,012 million Patacas in 2002, there was an increase to 23,929 million Patacas in 2008, and the stock of foreign investment amounted to 88,430 million Patacas (Macao Statistics and Census Services 2002-2009). The city has become a mega-construction zone, with dozen of new casinos and hotels arising in the span of several years (Macau Daily Times, July 30, 2010). Macao's world-class tourism facilities raised the attention and curiosity of nearby regions, and tourist arrivals increased from 7.44 million in 1999 to 21.75 million in 2009. With 111,012 million Patacas in gaming revenue, Macao exceeded Las Vegas and became the world's largest casino city. Also, to support the fast growing tourism industry, large amounts of foreign labor has been invited to the city. From 1999 to 2009, the number of guest workers increased from 32,183 to 74,905, accounting for nearly one third of Macao's total employment (Macao Statistics and Census Services 1999-2009).

Despite the tourism boom, Sheng and Tsui (2009a) observed that serious side effects have been emerging in the city during the boom years. Such effects include leakage, inflation, real estate overheating, "Dutch disease", overdependence on the gaming industry, crowding out of local business, negative impacts on the local youth, environmental degradation, deteriorating public order. From 2002 to 2009, trade deficits increased from 1,397 million Patacas to 29,229 million Patacas, the consumer price index (CPI) increased from 85.32 to 101.4, total real estate transactions increased from 5,069 million Patacas to 26,299 million Patacas, the gaming tax as a percentage of GDP increased from 14.16 to $26.77 \%$, the number of firm bankruptcies increased from 99 to 469, the number of school dropouts increased from 209 to 791 , mortality from respiratory illness increased from 172 to 226 , the number of noise complaints increased from 2515 to 3894, and the number of criminal cases increased from 9088 to 12,406 (Macao Statistics and Census Services 20022009). 


\subsection{Dominance of foreign investors}

It is generally believed that Macao liberalized its commercial gambling to international capital as an independent decision based on economic considerations. However, recent news has shaken this belief by revealing multiple players behind the scenes of Macao's decision. A Hong Kong Businessman, Richard Suen, sued Venetian, the largest foreign casino in Macao, for not paying promised rewards worth hundreds of millions of Patacas. He had helped Venetian lobby the Beijing government's top officers responsible for Macao affairs, helping Venetian successfully win a gaming license (Journal O Pulso de Macau, June 6, 2008). Vegas Chinese News (April 24, 2008) also reveals that Adelson, the owner of Venetian, following the Chinese government's requests, actively lobbied the US government and legislature not to hinder Beijing's Olympic bid and not to pass a resolution calling for a boycott against the Beijing Olympics. Adelson's "friendship" seems to have won the favor of China's leaders and may possibly have played a role in making the gaming liberalization in Macao possible.

Originally, only three gaming licenses were allowed in Macao. However, the local government later approved subcontracting for these licenses to other gaming firms. The Wynn Group, another multinational gaming enterprise, cashed in US\$900 million by subcontracting its Macao gaming license to the Australian PBL group with the Macao government's official approval (Singpao Daily, March 7, 2006). Soon after this liberalization of gaming, a former top government officer responsible for granting gaming licenses to foreign investors joined Venetian as one of its top-level managers, causing widespread suspicion about dubious connections between local government officials and foreign investors (Macao Daily News, March 18, 2003).

With better management and advertising skills, more international connections, and simply greater capital resources, foreign casinos grew rapidly at the expense of local casinos. The gaming sector opened up in 2002. Venetian, the first foreign gaming firm, opened its first casino in Macao in 2004. Consequently, we selected the period from 2004 to 2009 as shown in Table 1. MGM Grand, Melco PBL, Wynn, and Galaxy started their gaming businesses in Macao in 2007, 2006, 2006, and 2005, respectively. First, we may observe that foreign casino tycoons have significantly more capital than local businesses, with Venetian having about eleven times and Wynn having three times as much capital as the local SJM in 2009. In fact, SJM accounts for only $6 \%$ of the total capital of casinos in Macao, in contrast to the Venetian's more than 60\%. Second, the market share of SJM has decreased significantly since the gaming liberalization, from $100 \%$ in 2002 to 30\% in 2009. In fact, MGM Grand and Melco PBL are joint ventures between family members of Stanley Ho, the owner of SJM, and foreign firms. However, even after considering their share in the joint ventures, the total Ho family's market share only totals $40 \%$ of the Macao gaming market. Third, net profit (after tax) of SJM decreased drastically despite massive tourist arrivals during the period. While SJM recorded 5,560 million Patacas net profit in 2005, it shrunk to only 1,017 million Patacas in 2009. The Ho family's joint ventures even recorded net losses in 2009. Fourth, foreign casinos made considerable profit during this time. Venetian recorded 2,972 millions Patacas net profit in 2006, and Wynn cashed in 6,056 millions Patacas, mainly because of selling concessionaire to MGM Grand. In fact, Wynn Macao 
Table 1 Capital, revenue and profit of gaming enterprises in Macao 2004-2009 (million Patacas)

\begin{tabular}{lrrrrrr}
\hline & SJM & MGM Grand & MELCO PBL & VENETIAN & WYNN & GALAXY \\
\hline Capital 2004 & 6,714 & & & 3,662 & & \\
Revenue 2004 & 35,206 & & 3,247 & & \\
Profit 2004 & 4,044 & & 952 & & \\
Capital 2005 & 4,878 & & 7,075 & & 6,735 \\
Revenue 2005 & 34,409 & & 8,013 & & 4,015 \\
Profit 2005 & 5,560 & & & 2,372 & & 6 \\
Capital 2006 & 5,090 & & & 22,592 & 11,801 & 8,554 \\
Revenue 2006 & 35,222 & & 129 & 10,510 & 2,362 & 7,786 \\
Profit 2006 & 2,512 & & 159 & 2,972 & 6,056 & -450 \\
Capital 2007 & 6,935 & 248 & 11,525 & 39,452 & 13,492 & 9,201 \\
Revenue 2007 & 33,111 & 162 & 3,783 & 16,354 & 13,161 & 11,857 \\
Profit 2007 & 1,845 & -712 & $-1,041$ & 1,579 & 1,485 & 561 \\
Capital 2008 & 4,312 & -2 & 5,230 & 55,284 & 15,755 & 13,110 \\
Revenue 2008 & 28,832 & 8,794 & 15,582 & 26,048 & 18,192 & 13,243 \\
Profit 2008 & 747 & -251 & 152 & 1,414 & 2,118 & -362 \\
Capital 2009 & 4,684 & 120 & 2,382 & 49,069 & 13,691 & 8,747 \\
Revenue 2009 & 35,088 & 10,343 & 14,773 & 27,921 & 17,501 & 13,881 \\
Profit 2009 & 1,017 & -117 & $-1,435$ & 1,750 & 2,357 & 1,219 \\
\hline
\end{tabular}

Sources: Annual reports of SJM, MGM Grand, Melco PBL, Venetian, Wynn, and Galaxy

generated double the gaming revenue of its Las Vegas headquarter (Macau Daily Times, July 31, 2010).

The influence of foreign investors is growing rapidly, with their fast-increasing contributions to local employment and government revenue. Venetian is currently providing one sixth of Macao's public revenue, and one of its casino resorts in the Cotai Strip employs 12,000 people. An ambitious plan to hire 22,000 additional employees is underway (Macau Daily Times, July 16, 2010). The Venetian casino's strong bargaining power is reflected in its success in obtaining a piece of land covering 10.5 million square feet in the Cotai Strip, despite the extreme scarcity of Macao's land (Macau Daily Times, July 28, 2010). Wynn also plans to start new mega-construction on the land granted to them in the Cotai Strip (Macau Post, June 11, 2010). In contrast, the local SJM is still waiting for land in the Cotai Strip, which may be decisive for its long-run development and competitiveness in comparison to foreign competitors (Macau Daily Times, June 11, 2010).

Together with the Macao government, foreign investors have made efforts to bring in huge numbers of tourists, regardless of the fact that Macao is a small territory with a limited tourism carrying capacity. The biggest success for these investors is that they convinced China to ease its restrictions on people traveling from Mainland China to Macao so that, since 2003, Chinese citizens in the rich provinces' major cities can travel to Macao after a simple application. According to research by the Institute for Tourism Studies in 2003, Macao's tourism carrying capacity was around 15 million 
tourists (Xinhua News Agency, December 28, 2003). This number was exceeded in 2004, with around 17 million tourists (Macao Statistics and Census Services, 2004). With a buildup of infrastructure and the adaptive attitude of local people to the crowding, the tourism carrying capacity of Macao rose to 27 million visitors in 2007 (China News Agency, December 26, 2008). However, this was again exceeded with around 30 million tourists in 2008, approximately 60 times Macao's population (Macao Daily News, February 26, 2009).

\section{Conclusions}

We developed an urban economics model to analyze the diverging preferences of foreign investors and the host community with regard to a tourist city's openness in the presence of significant side effects. Foreign investors, focused chiefly on maximizing their returns on investment, have interest that are somewhat opposing to those of the invested city, when considered as a whole. If the interests and influences of foreign investors dominate a city's policymaking, the result may not be desirable for the host community. Foreign investors' profits are often produced at the expense of the majority of locals and the sustainability of the city's urban development.

Although the present study focuses on the "dark side" of foreign investment in the context of small tourism economies, we do not want to suggest that foreign investment should be judged negatively on the whole. In the case of Macao, foreign competition greatly enriches the services and choices provided for local customers. Luxury hotels, exotic restaurants, high-quality shops, theme parks, event venues, and other worldclass tourism facilities, as well as brand new services, are arising in the booming city. Macao residents used to go shopping and enjoy leisure activities in Hong Kong, because the home city was unable to provide quality goods and services. Today, however, Macao is considered a leisure and shopping paradise in "Greater China", with nearly 100,000 tourists visiting daily and enjoying its high-quality tourism services (Macao Statistics and Census Services 2009). Before gaming liberalization, Macao's local casinos were famous for their sub-standard physical facilities and for questionable customer service practices, such as pressing customers for tips. Today, local firms are establishing new, integrated casinos with facilities comparable to those of their foreign counterparts. The local firms are providing high-quality services and adopting best practices learned from foreign firms. In a broad sense, foreign investment has stimulated economic growth, bringing about significant progress for the city and improving welfare in the local community. Using its fast-increasing gaming revenue, the Macao government has invested some of these resources to improve the medical care system. In 2001, there was one doctor and one nurse for every 920 and 1,622 residents, respectively, compared to 810 and 1,322 in 2007. Educational facilities are also improving: 22.8 students shared one teacher in the educational system in the academic year 1999/2000, compared to 16.4 in 2006/2007 (Macao Statistics and Census Services 1999-2008).

As a pilot study mainly devoted to theoretical construction, this paper has some limitations that may be addressed in future research. First, the impact of foreign investment in tourist cities may be influenced by a city's size and overall level of development. 
Some tourist cities will have more fully developed sectors than others, i.e., diversified economies. This will influence how well the city can absorb the tourist trade. Future research may factor in size and location of cities as well as degrees of economic diversity and development. Having cities across the world with different characteristics in a study would help to demonstrate the importance of these and other factors. Second, the openness of cities may not be determined by an economic rationale; it depends on history, culture, and in particular, the federalist nature of the national system of government. Discussion of these issues in a broader national context with elaboration to political science literature may be of interest and relevance for city specific studies in this area. Third, although the side effects in many tourist cities across the world are the result of foreign investors, investors in many other tourist cities might be domestic. Theoretically, the paradox of overinvestment can be explained by externalities of both foreign and private investment. Differentiating the types and degrees of side effects of investments with regard to their origins may be of interest and relevance. Fourth, one case study might not be sufficient to validate the theoretical construction. In fact, as the only casino city in Greater China, Macao differs from other tourist cities, despite many similarities. Moreover, the casino industry also differs from other tourism-related sectors. To prove the validity of the model, comparative studies across tourist cities using exact values (numerical specification) of each variable are definitely needed. Lastly, the case study only lends empirical support to the existence of side effects and therefore supports the validity of the theoretical construction only to a certain degree. It is not shown in this paper whether side effects brought about by foreign investment in Macao's tourism industry have already exceeded its benefits or whether capital controls should be imposed as a consequence. In fact, comparing benefits against side effects entails quantifying openness, opportunities, a utility function, social, environmental and political side effects using appropriate criteria and an indexing system. As a pilot study mainly devoted to theory, we do not deepen our analysis to quantify the relevant variables. Therefore, determining whether foreign investment in tourism is excessive could be an area for future research.

\section{References}

Anwar S (2009) Sector specific foreign investment, labour inflow, economies of scale and welfare. Econ Model 26(3):626-630

Briassoulis H (2002) Sustainable tourism and the question of the commons. Ann Tour Res 29:1065-1085

Campbell T (2009) Learning cities: knowledge, capacity and competitiveness. Habitat Int 33(2):195-201

Carbone M (2005) Sustainable tourism in developing countries: poverty alleviation, participatory planning, and ethical issues. Eur J Dev Res 17:559-565

Chand S (2003) Economic trends in the pacific island countries. Pacif Econ Bull 18:1-15

China News Agency: December 26, 2008, Is expanding individual travel scheme appropriate medicine for Macao?

Chou KL, Chow NWS (2009) The roles of human capital and social capital in the economic integration of new arrivals from Mainland China to Hong Kong. Habitat Int 33(4):340-346

Copeland B (1991) Tourism, welfare, and de-industrialization in a small open economy. Economica 58:515529

Croes RR (2006) A paradigm shift to a new strategy for small island economies: embracing demand side economics for value enhancement and long term economic stability. Tour Manag 27:453-465

Dutt AK (1997) The pattern of direct foreign investment and economic growth. World Dev 25(11):19251936 
Galaxy Casino, Annual Reports, 2005-2009

Ghosh RN, Siddique M, Gabbay R (eds) (2003) Tourism and economic development: case studies from the Indian Ocean region. Ashgate, Aldershot

Gössling S (2001) Tourism, environmental degradation and economic transition: interacting process in a Tanzanian Coastal community. Tour Geograph 3:230-254

Gössling S, Schulz U (2005) Tourism-related migration in Zanzibar, Tanzania. Tour Geograph 7:43-62

Harrison D (2003) Themes in Pacific Island tourism. In: Harrison D (ed) Pacific Island tourism. Cognizant Communication Corporation, New York, pp 1-23

Hoti SM, McAleer R, Shareef R (2005) Modeling country risk and uncertainty in Small Island tourism economies. Tour Econ 11(2):159-183

Huong LTT, Sajor EE (2010) Privatization, democratic reforms, and micro-governance change in a transition economy: condominium homeowner associations in Ho Chi Minh City, Vietnam. Cities 27(1):2030

Journal O Pulso de Macau, Sands is accused of breaking promises, hundred millions debt owned by Hong Kong Businessman, 936, June 6, 2008

Kim C (2010) Place promotion and symbolic characterization of New Songdo City, South Korea. Cities 27(1):13-19

Kirby A, Modarres A (2010) The suburban question: an introduction. Cities 27(2):65-67

Liu ZH, Jenkins CL (1996) Country size and tourism development: a cross-nation analysis. In: Briguglio L, Archer B, Jafari J, Wall G (eds) Sustainable tourism in islands and small states; issues and policies. Printer, London, pp 90-117

Lloyd PJ (1996) The role of foreign investment in the success of Asian industrialization. J Asian Econ 7(3):407-433

Macao Daily News: March 18, 2003, Ho Hou In's resignation did not relate to a conflict of interest

Macao Daily News: February 26, 2009, Macao's true tourist arrivals is 23 million in 2008

Macao Statistics and Census Services, Yearbook of Statistics, 1999-2009

Macau Daily Times: June 11, 2010, SJM still waiting on Cotai

Macao Daily News: July 16, 2010, Sands, galaxy to Hire 22000

Macao Daily News: July 28, 2010: Tracy, sisk picked for Sands China

Macao Daily News: July 30, 2010, Leven: few weeks to catch up lag in Cotai

Macao Daily News: July 31, 2010, MSAR helps Wynn double quarter profits

Macau Post: June 11, 2010, Wynn plans to start construction on Cotai next year

Melco PBL Jogos, Annual Reports, 2006-2009

MGM Grand Paradise, Annual Reports, 2007-2009

Mowforth M, Munt I (2003) Tourism and sustainability: development and new tourism in the third world. Routledge, London

Musil R (2009) Global capital control and city hierarchies: an attempt to reposition Vienna in a world city network. Cities 26(5):255-265

Özdemir D (2010) Strategic choice for Istanbul: a domestic or international orientation for logistics? Cities 27(3):154-163

Peri G, Urban D (2006) Catching-up to foreign technology? Evidence on the "Veblen-Gerschenkron" effect of foreign investments. Reg Sci Urban Econ 36(1):72-98

Potter R (1993) Basic needs and development in the small island states of the Eastern Caribbean. In: Lockart DG, Drakakis-Smith D, Schembri J (eds) The development process in small island states. Routledge, London, pp 92-116

Rafiqui PS, Gentile M (2009) Vientiane. Cities 26(1):38-48

Relly JE, Sabharwal M (2009) Perceptions of transparency of government policymaking: a cross-national study. Gov Inf Q 26(1):148-157

Scheyvens R, Momsen JH (2008) Tourism and poverty reduction: issues for small island states. Tour Geograph 10:22-41

Shaw BJ, Shaw G (1999) Sun, sand and sales: enclave tourism and local entrepreneurship in Indonesia. Curr Issues Tour 2:68-81

Sheng L, Tsui YM (2009a) Casino booms and local politics: the city of Macao. Cities 26:67-73

Sheng L, Tsui YM (2009b) A general equilibrium approach to tourism and welfare: the case of Macao. Habitat Int 33(4):419-424

Sheng L, Tsui YM (2009c) Taxing tourism: enhancing or reducing welfare? J Sustain Tour 17(5):627-635 
Sheng L, Tsui YM (2010) Foreign investment in tourism: the case of Macao as a small tourism economy. Tour Geograph 12(2):173-191

Sociedade de Jogos de Macau (SJM), Annual Reports, 2004-2009

Singpao Daily: March 7, 2006, PBL Buys Wynn's Gambling License for 7 bn

Singtao Daily: May 2, 2006, Labor Day Demonstration in Macao, 4 Hours Traffic Jam

Singtao Daily: May 2, 2010, 'Stone War' against Police

Stonich S (2003) The political ecology of marine protected areas: the case of the Bay Islands. In: Gössling S (ed) Tourism and development in tropical islands: political ecology perspectives. Edward Elgar, Cheltenham, pp 121-147

Tang UW, Sheng N (2009) Macao. Cities 26(4):220-231

Turnock D. (1997) Urban and regional restructuring in eastern Europe: the role of foreign investment. GeoJournal 42:457-464

UNWTO/UNEP (1997) Guidelines for carrying capacity assessment for tourism in Mediterranean Coastal Areas, Priority Action Program. Regional Activity Centre, Split

Vegas Chinese News: April 24, 2008, Macao and olympics; gaming license and Casino King

Venetian Macau, Annual Reports, 2004-2009

Wei D, Leung CK, Luo J (2006) Globalizing Shanghai: foreign investment and urban restructuring. Habitat Int 30:231-244

Wilkinson PF (1999) Caribbean cruise tourism: delusion? Illusion? Tour Geograph 1:261-282

Williams AM, Hall CM (2000) Tourism and migration: new relationships between production and consumption. Tour Geograph 2:5-27

Williams AM, Hall CM (2002) Tourism, migration, circulation and Mobility. The contingencies of time and place. In: Hall CM, William AM (eds) Migration and tourism. New relationships between production and consumption. Kluwer, Dordrecht, pp 1-51

Wu F (2001) China's recent urban development in the process of land and housing marketisation and economic globalization. Habitat Int 25:273-289

Wu JP, Barnes T (2008) Local planning and global implementation: foreign investment and urban development of Pudong, Shanghai. Habitat Int 32(3):364-374

Wynn Resorts, Annual Reports, 2006-2009

Xinhua News: December 28, 2003, Over 10 million Tourist Prove Macao's Charm

Zhang Q, Felmingham B (2001) The relationship between inward direct foreign investment and China's provincial export trade. China Econ Rev 12(1):82-99 